\title{
The relationship between ownership structure and earnings quality in the French context
}

\author{
Wafa Masmoudi Ayadi *, Younes Boujelbène \\ Faculty of Economics and Management, University of SFAX, Tunisia \\ *Corresponding author E-mail: wafamasmoudi@yahoo.fr
}

\begin{abstract}
The main objective of this paper is to investigate the relationship between ownership structure and earnings quality, proxied by earnings management and informativeness. This study focuses on a sample of 117 French companies belonging to the SBF 250 index during the period 2003-2011. For our analysis, we use the panel data econometrics and, more specifically, the method of Panel Corrected Standard Errors. The results of linear regressions show that managerial ownership has a positive impact on the earnings management and reveal that ownership concentration and institutional ownership have a positive impact on the earnings informativeness. In addition, the results of this study show the existence of non-linear relationship only for ownership concentration and institutional ownership.
\end{abstract}

Keywords: Ownership Structure, Earnings Quality, Earnings Management, Earnings Informativeness.

\section{Introduction}

The agency theory posits that the separation of ownership and control leads to the conflicts of interests between managers and owners. These conflicts arise when managers seek to maximize their interests and engage in activities that are not in line with the objective of maximizing shareholders' wealth.

To alleviate these conflicts of interests, the shareholders put in place several corporate governance mechanisms. Previous studies are generally unanimous that board of directors and audit committee are the primary mechanisms of the internal control system serving to monitor the financial reporting process and to reduce the discretionary power of managers. Besides these mechanisms, the corporate governance system gives an important role to the ownership structure in resolving agency conflicts.

Empirical studies on ownership structure are quite old. We find that the majority of these studies are limited to examine the link between ownership structure and corporate performance. But following the various financial scandals, the studies related to the ownership structure have been focused, instead, on several measures of earnings quality because the quality of accounting earnings was called in question by fraudulent manipulations and deviant behaviors of managers.

The topic of earnings quality has received great attention in recent years by accounting researchers and many participants in the financial reporting process such as standard setters, preparers of financial statements, auditors and analysts. Earnings quality is a multidimensional concept and there is no agreed-upon definition. In the accounting literature, various attributes, such as earnings management, persistence, predictability, smoothness, informativeness, conservatism and timeliness, have been developed to assess the earnings quality concept. Like Warfield et al. (1995), Gabrielsen et al. (2002) and Sánchez-Ballesta \& García-Meca (2007), we adopt in this study two different measures of earnings quality which are earnings management and informativeness. Earnings management is defined as the intentional interference in the external financial reporting process, with the intent of obtaining some private gain (Schipper 1989). While, earnings informativeness is defined as the ability of one or more accounting numbers to explain variation in stock returns (Francis et al. 2006).

At the theoretical level, the ownership structure as a governance mechanism appears as a means to ensure a better quality of accounting information by reducing the earnings management and improving the earnings informativeness. But at the empirical level, previous studies do not lead to a consensus regarding the role of ownership structure in improving the quality of financial information. The ambiguity that emerges from previous studies on this subject and the scarcity of studies examining the relationship between ownership structure, discretionary accruals and informativeness in the French context motivated the choice of this research. In this regard, the key question addressed by this study is: to what extent the ownership structure affects the earnings quality, proxied by earnings management and informativeness?

The remainder of this paper proceeds as follows. Section 2 reviews the literature and develops testable hypotheses. Section 3 describes the research methodology. Section 4 presents and discusses the results. Section 5 summarizes and concludes the paper.

\section{Literature review and hypothesis develop- ment}

Consistent with previous studies, we identify three distinct aspects of the ownership structure namely managerial ownership, ownership concentration and institutional ownership. In this section, we present a review of the literature on the relationship between each aspect of the ownership structure and the earnings quality.

\subsection{Managerial ownership and earnings quality}


Previous researches examining the relationship between managerial ownership and earnings quality generally lead to contradictory and inconclusive results. Some studies show a linear relationship while others highlight a non-linear relationship.

In the context of the linear relationship, Warfield et al. (1995), using a sample of American firms during the period 1988-1990, find that the level of managerial ownership is positively associated with the informativeness of accounting earnings and inversely related to the earnings management as measured by discretionary accruals. In accordance with the study of Warfield et al. (1995), Ebrahim (2007), Ali et al. (2008), Banderlipe (2009) and Alves (2012) show a negative relationship between managerial ownership and earnings management. Their results confirm the convergence of interest hypothesis and suggest that the higher managerial ownership, the lower the level of discretionary accruals. However, Cheng \& Warfield (2005), Al-Fayoumi et al. (2010) and Charfeddine et al. (2013) find that managerial ownership is associated with higher levels of earnings management. Unlike to Warfield et al. (1995), Gabrielsen et al. (2002) find in the Danish context a significant negative relationship between the managerial ownership and the earnings informativeness and a positive but not significant relationship between the managerial ownership and the level of earnings management.

Regarding the non-linear relationship, Teshima \& Shuto (2008) find a significant non-monotonic relationship between managerial ownership and discretionary accruals, which confirms the existence of two effects. Equally, González \& García-Meca (2013) show that the relationship between the insider ownership and the level of discretionary accruals is non-linear. In fact, when the insider ownership increases, the earnings management practice seems to be reduced. But, when the insider ownership reaches and exceeds a certain threshold (14.1\%), the situation is reversed with an increase in earnings management. Also, Yeo et al. (2002) confirm the existence of a non-linear relationship between managerial ownership and earnings informativeness for companies listed on the Singapore Stock Exchange. At low levels of management ownership, the information content of accounting earnings increases with managerial ownership, which is consistent with the predictions of agency theory and the results reported by Warfield et al. (1995). However, at high levels of management ownership, the earnings informativeness decreases with managerial ownership pursuant to the entrenchment effect supported by Morck et al. (1988). In the same vein, Sánchez-Ballesta \& García-Meca (2007) find a non-linear relationship between insider ownership and discretionary accruals and between insider ownership and earnings informativeness for Spanish firms listed on the Madrid Stock Exchange during the period 1999-2002. These authors argue that internal ownership contributes both to improve the information content of earnings and to constrain the earnings management when the proportion of shares held by insiders is not too high. But when this proportion becomes very high, the insiders are entrenched and the relationship between insider ownership, discretionary accruals and earnings informativeness reverses. Likewise, Ghosh \& Moon (2010) find a non-linear association between the ownership of Chief Executive Officer (CEO) and the earnings informativeness proxied by Earnings Response Coefficient (ERC). In fact, when the level of CEO ownership is low, the Earnings Response Coefficient increases with managerial ownership and earnings are considered as being more informative about future firm performance. But, when the level of CEO ownership exceeds $25 \%$, the Earnings Response Coefficient decreases and earnings are perceived as being less informative.

Given that the empirical results are not consistent, we simply expect the existence of a relationship between managerial ownership and the quality of accounting earnings but without predict its sense. In this regard, we propose the following hypothesis:

H1: The managerial ownership is related to the earnings quality.

\subsection{Ownership concentration and earnings quality}

Previous studies addressing the relationship between ownership concentration and earnings quality are divergent. Some studies support the existence of a linear relationship between these two variables while others support a non-linear relationship between them. In the context of the linear relationship, the results of empirical studies are not consistent about the sense of the relationship (positive or negative).

Regarding the negative relationship, Fan \& Wong (2002) find for a sample of 977 firms belonging to seven East Asian economies (Hong Kong, Indonesia, Malaysia, Singapore, South Korea, Taiwan and Thailand) that concentrated ownership is associated with low earnings informativeness. These authors suggest two explanations for this negative association. The first explanation is based on the entrenchment hypothesis (Morck et al. 1988). In fact, the ownership concentration gives rise to agency conflicts between owners and outside investors. The owners tend to disclose accounting information while promoting their own interests, which leads to a loss of credibility of reported earnings to outside investors. The second explanation is based on the information effect argument. In this perspective, the ownership concentration allows to limit the information disclosure to the public and to prevent leakage of specific information to competitors, which presumably weakens the information content of earnings disclosed to outside investors. Equally, Donnelly \& Lynch (2002) show that concentrated outside ownership in the UK negatively affects the informativeness of accounting earnings. The authors suggest that more non-accounting information is collected and disseminated in firms having a concentrated outside ownership, which results in a loss of information content of accounting earnings. In the same vein, Firth et al. (2006) provide evidence that earnings informativeness decreases when ownership concentration increases and they explain this negative relationship by the entrenchment hypothesis. In fact, large shareholders may influence firms to adopt accounting policies that reflect the needs and the interests of owners rather than the economic substance of transactions, which presumably diminishes the quality of accounting earnings.

Concerning the positive relationship, Jung \& Kwon (2002) document that earnings become more informative when holdings of the owner-largest shareholder increase and they explain this relationship by the convergence of interest hypothesis. These authors argue that the increase of the owner-largest shareholder holdings contributes to a reduction of agency costs and, in this context, the owner-largest shareholder behaves in a way to maximize firm value and impose fewer contractual constraints to the firm. This will reduce the practice of earnings management, resulting in higher earnings quality and informativeness. In the same vein, Ben Slama et al. (2007) find a positive relationship between ownership concentration and earnings informativeness in the American context. But, they do not find any significant relationship between these two variables in the French context. Based on a sample of 34 Portuguese firms, Alves (2012) notifies that earnings management is significantly lower in firms with higher ownership concentration. The author confirms the efficient monitoring hypothesis which suggests that the largest shareholders tend to reduce the level of managerial opportunism.

Equally, relying on a sample of 31 Tunisian listed companies during the period 1998-2009, Halioui \& Jerbi (2012) find that the presence of blockholders improves the quality of accounting earnings by reducing the level of earnings management. But, in case of declining premanaged earnings, the authors note that the presence of blockholders encourages the leaders to manage earnings upward in order to hide the declining performance. In the Nigerien context, Usman \& Yero (2012) show a negative association between the ownership concentration and the magnitude of earnings management. By examining a sample of 29 companies listed on the Abu Dhabi Securities Exchange, Ellili (2013) notes that the blockholders ownership negatively affects the level of discretionary accruals. So, the presence of blockholders in the ownership structure of the company ensures a better quality of accounting information. 
In the context of the non-linear relationship, Kammoun \& Bouazizi (2011) show, on a sample of 14 Tunisian listed companies, that firstly the relationship between ownership concentration and earnings management is significantly negative in accordance with the information effect argument. Then, this relationship becomes positive from a definite threshold of ownership concentration in accordance with the entrenchment hypothesis. However, these authors show that the concentrated ownership is associated with low earnings informativeness when the level of ownership concentration is low and it is associated with high earnings informativeness when the level of ownership concentration is high.

Given the divergence of empirical results, we anticipate the existence of a relationship between ownership concentration and earnings quality but without predict its sense. Then, we develop the following hypothesis:

$\mathrm{H} 2$ : The ownership concentration is related to the earnings quality.

\subsection{Institutional ownership and earnings quality}

A review of the literature shows that the previous studies examine both linear and non-linear relationship between institutional ownership and earnings quality and offer contrasted conclusions. Regarding the linear relationship, there is no consensus on terms of positive or negative signs.

In the context of the positive relationship, some researchers provide evidence that firms with high level of institutional ownership are less likely to manage earnings (Bushee 1998, Chung et al 2002, Jiambalvo et al. 2002, Hadani et al. 2011). More specifically, Njah \& Jarboui (2010) report that in the Tunisian context the dedicated institutional investors (pension funds and undertakings for collective investment in transferable securities) allow hindering some earnings management practice. In addition, Hashim \& Devi (2012) find a positive association between institutional ownership and accruals quality in Malaysia and, therefore, confirm the active monitoring hypothesis. These authors conclude that the presence of institutional investors not only improves governance practices but contributes to a better quality of accounting information since it allows mitigate the earnings management activity. Equally, Velury \& Jenkins (2006) document a positive relationship between institutional ownership and earnings quality, which supports the idea that institutional investors monitor the financial reporting process and contribute to a better quality of accounting information. But, they note that concentrated shareholdings in the hands of institutional investors may negatively affect the quality of reported earnings. In the same vein, Jung \& Kwon (2002), Kwak \& Armitage (2009) and Sarikhani \& Ebrahimi (2011) find that the information content of accounting earnings increases with institutional ownership, which confirms the active monitoring role of institutional investors.

In the context of the negative relationship, Cheng \& Reitenga (2001) report that institutional ownership is highly associated with income increasing earnings management. Furthermore, Chekili (2012) investigates a sample of 20 Tunisian companies listed during the period 2000-2009 and argue that financial institutions encourage the leaders to manage earnings. In addition, Salajeghe et al. (2012) examine a sample of 212 companies listed on the Tehran Stock Exchange during the period 2006-2008 and conclude that the presence of institutional investors leads to an increase in earnings management. In the same context, Emamgholipour et al. (2013) find also a positive relationship between the institutional ownership and the level of discretionary accruals.

Concerning the non-linear association, Koh (2003) shows that the relationship between institutional ownership and income increasing discretionary accruals changes depending on the level of institutional ownership. More precisely, the author finds firstly a positive association when the level of institutional ownership is low, which confirms the idea that transient institutional investors encourage the managers to manage earnings upwards. Secondly, he finds that this association becomes negative when the level of institutional ownership is high. In this regard, he concludes that long-term institutional investors are able to dissuade the earnings management practice.

Kammoun \& Bouazizi (2011) find a significant negative relationship between institutional ownership and earnings management for both linear and quadratic terms. In addition, these authors find a positive and significant relationship between institutional ownership and earnings informativeness for both linear and quadratic terms. So, in the Tunisian context, institutional investors adopt an active behavior in order to reduce the accounting manipulations and improve the value relevance of accounting earnings.

Since the empirical results are divergent, we anticipate the existence of a relationship between institutional ownership and earnings quality but without predict its sense. Accordingly, our third hypothesis can be stated as follows:

H3: The institutional ownership is related to the earnings quality.

\section{Methodology}

\subsection{Sample and data description}

Our empirical study focuses on a sample of French listed companies belonging to the SBF 250 index over the period 2003-2011. We excluded first of all the financial companies (banks, insurance companies, investment companies and real estate companies) because they are characterized by a specific regulations related to financial statement presentation and governance. Then, we eliminated the foreign companies and the companies whose closing date is different from 31 December. This selection procedure allowed us to have a final sample of 117 companies over nine years, i.e., 1,053 observations.

Regarding data collection, the accounting and financial data were obtained from the Worldscope database and the market data were collected from the Datastream database. Whereas, the data related to the ownership structure were collected manually from annual reports and reference documents available on the website of the Financial Markets Authority AMF (Autorité des Marchés Financiers).

\subsection{Variables measurement}

\subsubsection{Measuring the dependent variable: earnings quality}

In our models, earnings quality is the dependent variable. In accordance with Warfield et al. (1995), Gabrielsen et al. (2002) and Sánchez-Ballesta \& García-Meca (2007), we use in this research two different measures of the earnings quality: an accountingbased measure that is the earnings management and a marketbased measure that is the earnings informativeness.

\section{Earnings management}

Based on accounting literature, we can note that discretionary accruals are generally used as a means to assess the level of earnings management. In our study, discretionary accruals are estimated using the model of Kothari et al. (2005) which looks as follow:

$\mathrm{TA}_{\mathrm{i}, \mathrm{t}} / \mathrm{A}_{\mathrm{i}, \mathrm{t}-1}=\beta_{0}\left(1 / \mathrm{A}_{\mathrm{i}, \mathrm{t}-1}\right)+\beta_{1}\left((\Delta \mathrm{REV}-\Delta \mathrm{REC}) / \mathrm{A}_{\mathrm{i}, \mathrm{t}-1}\right)+\beta_{2}\left(\mathrm{PPE} / \mathrm{A}_{\mathrm{i}, \mathrm{t}-}\right.$ $\left.{ }_{1}\right)+\beta_{3} \operatorname{ROA}_{\mathrm{i}, \mathrm{t}-1}+\varepsilon_{\mathrm{i}, \mathrm{t}}$

Where TA represents the total of accruals defined as the difference between earnings and operating cash flow, $\mathrm{A}_{\mathrm{i}, \mathrm{t}-1}$ represents the total assets in year $\mathrm{t}-1, \triangle \mathrm{REV}$ is the change in revenues, $\triangle \mathrm{REC}$ is the change in net receivables, PPE represents the gross value of property, plant, and equipment, $\mathrm{ROA}_{\mathrm{i}, \mathrm{t}-1}$ is the return on assets in year $\mathrm{t}-1, \varepsilon$ is the residual terms which represent the discretionary accruals.

Given that in this study we focus on the magnitude rather than the direction of the discretionary accruals, we use the absolute value of discretionary accruals (ACD) as a proxy for earnings management. The absolute value of discretionary accruals provides an inverse measure of the earnings quality to the extent that a higher level of absolute discretionary accruals corresponds to a lower accounting quality. 


\section{Earnings informativeness}

Like Warfield et al. (1995) and Gabrielsen et al. (2002), we measure the informativeness of earnings in this study by regressing stock returns on accounting data and we adopt the following regression:

$\mathrm{RET}_{\mathrm{i}, \mathrm{t}}=\beta_{0}+\beta_{1} \mathrm{EPS}_{\mathrm{i}, \mathrm{t}}+\varepsilon_{\mathrm{i}, \mathrm{t}}$

Where $\mathrm{RET}_{\mathrm{i}, \mathrm{t}}$ is the 15-month stock return ending three months after fiscal year-end, EPS ${ }_{i, t}$ is the earnings-per-share for firm i in year $t$ divided by the share price at the beginning of the period, $\varepsilon$ is the error term.

\subsubsection{Measuring the independent variable: ownership struc- ture}

In our models, ownership structure is the independent variable. Following the previous studies, we classify the ownership structure into three groups, namely, managerial ownership, ownership concentration and institutional ownership.

Managerial ownership (MAN): we measure the managerial ownership as being the percentage of capital held by the managers. Ownership concentration (CON): we measure the ownership concentration as being the percentage of capital held by the largest shareholder.

Institutional ownership (INST): we measure the institutional ownership as being the percentage of capital held by institutional investors.

\subsubsection{Measuring the control variables}

In order to identify other determinants of earnings quality, we introduce the following variables:

Firm size (FSIZE): this variable is calculated as the natural logarithm of market value of equity.

Leverage (LEV): this variable is calculated as the debt to total assets ratio.

Growth (GROW): this variable is measured by the market-tobook ratio equal to the report between the market value and the book value of equity.

Adoption of the International Financial Reporting Standards (IFRS): this variable is measured as a binary variable taking the value one for observations in the post-IFRS period, and zero for observations in the pre-IFRS period.

\subsection{Models specification}

The objective of this study is to test the impact of ownership structure on the earnings quality assessed by earnings management and earnings informativeness in the French context. To achieve this objective, we firstly propose the following two models on panel data. In the first model, we test the linear relationship between the different aspects of ownership structure and the absolute value of discretionary accruals. In the second model, we introduce quadratic terms related to the ownership structure in order to test the non-linear relationship.

Model 1: $\operatorname{ACD}_{\mathrm{i}, \mathrm{t}}=\beta_{0}+\beta_{1} \mathrm{MAN}_{\mathrm{i}, \mathrm{t}}+\beta_{2} \mathrm{CON}_{\mathrm{i}, \mathrm{t}}+\beta_{3} \mathrm{INST}_{\mathrm{i}, \mathrm{t}}+\beta_{4}$ FSIZE $_{i, t}+\beta_{5}$ LEV $_{\mathrm{i}, \mathrm{t}}+\beta_{6} \mathrm{GROW}_{\mathrm{i}, \mathrm{t}}+\beta_{7}$ IFRS $_{\mathrm{i}, \mathrm{t}}+\varepsilon_{\mathrm{i}, \mathrm{t}}$

Model 2: $\mathrm{ACD}_{\mathrm{i}, \mathrm{t}}=\beta_{0}+\beta_{1} \mathrm{MAN}_{\mathrm{i}, \mathrm{t}}+\beta_{2} \mathrm{MAN}_{\mathrm{i}, \mathrm{t}}^{2}+\beta_{3} \mathrm{CON}_{\mathrm{i}, \mathrm{t}}+\beta_{4}$ $\mathrm{CON}_{\mathrm{i}, \mathrm{t}}^{2}+\beta_{5} \mathrm{INST}_{\mathrm{i}, \mathrm{t}}+\beta_{6} \mathrm{INST}_{\mathrm{i}, \mathrm{t}}^{2}+\beta_{7} \mathrm{FSIZE}_{\mathrm{i}, \mathrm{t}}+\beta_{8} \mathrm{LEV}_{\mathrm{i}, \mathrm{t}}+\beta_{9}$ GROW $_{\mathrm{i}, \mathrm{t}}+\beta_{10}$ IFRS $_{\mathrm{i}, \mathrm{t}}+\varepsilon_{\mathrm{i}, \mathrm{t}}$

Secondly, we propose the following two models on panel data to assess the effect of ownership structure on the earnings informativeness. The first model deals with the linear relationship, whereas the second model focuses on the non-linear relationship.

Model 3: $\mathrm{RET}_{\mathrm{i}, \mathrm{t}}=\beta_{0}+\beta_{1} \mathrm{EPS}_{\mathrm{i}, \mathrm{t}}+\beta_{2} \mathrm{MAN}_{\mathrm{i}, \mathrm{t}} * \mathrm{EPS}_{\mathrm{i}, \mathrm{t}}+\beta_{3} \mathrm{CON}_{\mathrm{i}, \mathrm{t}} *$ $\mathrm{EPS}_{\mathrm{i}, \mathrm{t}}+\beta_{4} \mathrm{INST}_{\mathrm{i}, \mathrm{t}} * \mathrm{EPS}_{\mathrm{i}, \mathrm{t}}+\beta_{5}$ FSIZE $_{\mathrm{i}, \mathrm{t}} * \mathrm{EPS}_{\mathrm{i}, \mathrm{t}}+\beta_{6} \mathrm{LEV}_{\mathrm{i}, \mathrm{t}} *$ $\mathrm{EPS}_{\mathrm{i}, \mathrm{t}}+\beta_{7} \mathrm{GROW}_{\mathrm{i}, \mathrm{t}} * \mathrm{EPS}_{\mathrm{i}, \mathrm{t}}+\beta_{8} \mathrm{IFRS}_{\mathrm{i}, \mathrm{t}} * \mathrm{EPS}_{\mathrm{i}, \mathrm{t}}+\varepsilon_{\mathrm{i}, \mathrm{t}}$

Model 4: $\mathrm{RET}_{\mathrm{i}, \mathrm{t}}=\beta_{0}+\beta_{1} \mathrm{EPS}_{\mathrm{i}, \mathrm{t}}+\beta_{2} \mathrm{MAN}_{\mathrm{i}, \mathrm{t}} * \mathrm{EPS}_{\mathrm{i}, \mathrm{t}}+\beta_{3} \mathrm{MAN}_{\mathrm{i}, \mathrm{t}}^{2}$ $* \mathrm{EPS}_{\mathrm{i}, \mathrm{t}}+\beta_{4} \mathrm{CON}_{\mathrm{i}, \mathrm{t}} * \mathrm{EPS}_{\mathrm{i}, \mathrm{t}}+\beta_{5} \mathrm{CON}_{\mathrm{i}, \mathrm{t}}^{2} \mathrm{EPS}_{\mathrm{i}, \mathrm{t}}+\beta_{6} \mathrm{INST}_{\mathrm{i}, \mathrm{t}} *$ $\mathrm{EPS}_{\mathrm{i}, \mathrm{t}}+\beta_{7} \mathrm{INST}_{\mathrm{i}, \mathrm{t}}^{2} * \mathrm{EPS}_{\mathrm{i}, \mathrm{t}}+\beta_{8}$ FSIZE $_{\mathrm{i}, \mathrm{t}} * \mathrm{EPS}_{\mathrm{i}, \mathrm{t}}+\beta_{9} \mathrm{LEV}_{\mathrm{i}, \mathrm{t}} *$ $\mathrm{EPS}_{\mathrm{i}, \mathrm{t}}+\beta_{10} \mathrm{GROW}_{\mathrm{i}, \mathrm{t}} * \mathrm{EPS}_{\mathrm{i}, \mathrm{t}}+\beta_{11}$ IFRS $_{\mathrm{i}, \mathrm{t}} * \mathrm{EPS}_{\mathrm{i}, \mathrm{t}}+\varepsilon_{\mathrm{i}, \mathrm{t}}$

\subsection{Estimation method}

To select the best estimation method, we perform the following econometric tests: the test of individual effects presence, the Hausman test, the test of heteroscedasticity and the test of autocorrelation.

In the four models, the results of the test of individual effects presence show a significant Fisher statistic, allowing us to reject the null hypothesis of the absence of specific effects and to introduce in each model individual effects. For the sake of determining whether these effects are fixed or random, we carry out the Hausman test. This test shows a p-value below the threshold of $10 \%$ in the four models, allowing us to choose the fixed effects model. In addition, we find that the four models jointly present problems of heteroscedasticity and autocorrelation. In this context, we adopt the method proposed by Beck \& Katz (1995) that is the method of Panel Corrected Standard Errors. According to Beck \& Katz (1995), this method is better than the method of Generalized Least Squares since it allows eliminating the problems of heteroscedasticity and autocorrelation and, therefore, leads to more robust results.

\section{Empirical results}

\subsection{Descriptive statistics}

Table 1 presents the descriptive statistics of the variables used in this study.

Table 1: Descriptive Statistics

\begin{tabular}{lllllll}
\hline Variables & Obs & Mean & Median & $\begin{array}{l}\text { Std. } \\
\text { dev. }\end{array}$ & Minimum & Maximum \\
\hline ACD & 1052 & 0.044 & 0.025 & 0.065 & 0.000 & 0.995 \\
RET & 1049 & 0.346 & 0.201 & 1.160 & -0.934 & 5.222 \\
EPS & 1049 & 0.047 & 0.062 & 0.295 & -3.904 & 4.866 \\
MAN & 1051 & 0.074 & 0.000 & 0.176 & 0.000 & 0.970 \\
CON & 1050 & 0.325 & 0.283 & 0.220 & 0.000 & 0.980 \\
INST & 1051 & 0.123 & 0.000 & 0.248 & 0.000 & 0.897 \\
FSIZE & 1051 & 6.693 & 6.302 & 2.043 & 1.363 & 11.821 \\
LEV & 1053 & 0.231 & 0.223 & 0.142 & 0.000 & 0.838 \\
GROW & 1051 & 2.443 & 1.743 & 2.171 & -1.559 & 13.807 \\
\hline The
\end{tabular}

The notation used in the above Table is defined as follows: ACD is the absolute value of discretionary accruals estimated by the error term of the Kothari et al. (2005) model; RET is the 15-month stock return; EPS is the earnings-per-share in year $\mathrm{t}$ standardized by the stock price in year $\mathrm{t}-1$; MAN is the percentage of capital held by the managers; $\mathrm{CON}$ is the percentage of capital held by the largest shareholder; INST is the percentage of capital held by the institutional investors; FSIZE is the natural logarithm of market value of equity; LEV is the ratio of total debt to total assets; GROW is the market-to-book ratio equal to the report between the market value and the book value of equity.

The results reported in Table 1 show that the average absolute value of discretionary accruals calculated using the Kothari et al. (2005) model is 0.044 . This measure of earnings management is characterized by a median of 0.025 and a standard deviation of 0.065 . The values taken by this measure varies between 0 and 0.995 .

It also appears from this Table that the 15-month stock return has an average of 0.346 and a standard deviation of 1.160 . The descriptive statistics reveal that the ratio of earnings-per-share in year $\mathrm{t}$ standardized by the stock price in year $\mathrm{t}-1$ is characterized by an average of 0.047 and a standard deviation of 0.295 . This ratio exhibits a minimum of -3.904 and a maximum of 4.866 .

Regarding the ownership structure, the percentage of capital held by managers is relatively low in our sample since the average value is $7.4 \%$. We note that the largest shareholder holds on average $32.5 \%$ of the capital. So, we can conclude that the ownership is relatively concentrated in the French context. The results of the descriptive analysis highlight that the participation of institutional investors in the capital of French companies is highly dispersed since institutional ownership varies between $0 \%$ and $89.7 \%$ with an average of $12.3 \%$. Therefore, we can conclude that the role of 
institutional investors is not too powerful in companies composing our sample.
Concerning the control variables, we find that the firm size measured by the natural logarithm of market value of equity, presents a fairly high average of 6.693 and a standard deviation of 2.043 ,

Table 2: Spearman Correlation Matrix

\begin{tabular}{lllllll}
\hline & EPS & MAN & CON & INST & FSIZE & LEV \\
\hline EPS & 1 & & & & & \\
MAN & $-0.087^{* * *}$ & 1 & & & & \\
CON & $0.085^{* * *}$ & $0.058^{*}$ & 1 & & & \\
INST & $0.056^{*}$ & $-0.173^{* * *}$ & $-0.380^{* * *}$ & 1 & & \\
FSIZE & $0.089^{* * *}$ & $-0.468^{* * *}$ & $-0.284^{* * *}$ & $0.360^{* * *}$ & 1 & \\
LEV & 0.006 & $-0.163 * * *$ & -0.050 & $0.058^{*}$ & $0.148^{* * *}$ & 1 \\
GROW & $-0.069^{* *}$ & $0.095^{* * *}$ & 0.009 & -0.043 & $0.190^{* * *}$ & $-0.202^{* * *}$ \\
IFRS & $0.053^{*}$ & -0.042 & -0.012 & 0.019 & $0.061^{* *}$ & $-0.030^{* *}$ \\
\hline
\end{tabular}

$*, * *, * * *$ represent statistical significance at $10 \%, 5 \%$ and $1 \%$ levels.

The notation used in the above Table is defined as follows: EPS is the earnings-per-share in year $t$ standardized by the stock price in year t-1; MAN is the percentage of capital held by the managers; CON is the percentage of capital held by the largest shareholder; INST is the percentage of capital held by the institutional investors; FSIZE is the natural logarithm of market value of equity; LEV is the ratio of total debt to total assets; GROW is the market-to-book ratio equal to the report between the market value and the book value of equity; IFRS is a dummy variable that takes the value of 1 for observations in the post-IFRS period and 0 otherwise.

Table 3: Regression Results Examining the Relationship between Ownership Structure and Earnings Management

\begin{tabular}{|c|c|c|c|c|}
\hline \multirow{2}{*}{ Variables } & \multicolumn{2}{|l|}{ Model 1} & \multicolumn{2}{|l|}{ Model 2} \\
\hline & Coefficients & $\mathrm{Z}$ & Coefficients & $\mathrm{Z}$ \\
\hline Intercept & 0.0657 & $4.22 * * *$ & 0.0723 & $4.77 * * *$ \\
\hline MAN & 0.0219 & $2.26 * *$ & 0.0295 & 0.84 \\
\hline $\mathrm{CON}$ & -0.0103 & -0.94 & -0.0654 & $-1.98 * *$ \\
\hline $\mathrm{CON}^{2}$ & & & 0.0733 & $1.75^{*}$ \\
\hline INST & 0.0015 & 0.20 & 0.0295 & 0.89 \\
\hline INST $^{2}$ & & & -0.0418 & -1.02 \\
\hline FSIZE & -0.0052 & $-2.67 * * *$ & -0.0052 & $-2.76 * * *$ \\
\hline LEV & 0.0224 & 1.45 & 0.0199 & 1.25 \\
\hline GROW & 0.0048 & $4.40 * * *$ & 0.0048 & 4.39 *** \\
\hline IFRS & -0.0025 & -0.58 & -0.0023 & -0.55 \\
\hline $\begin{array}{l}\mathrm{N} \\
\mathrm{R}^{2} \\
\text { Wald chi2 }\end{array}$ & $\begin{array}{l}1048 \\
0.1959 \\
61.29 * * *\end{array}$ & & $\begin{array}{l}1048 \\
0.1968 \\
67.75^{* * *}\end{array}$ & \\
\hline
\end{tabular}

$*, * *, * * *$ represent statistical significance at $10 \%, 5 \%$ and $1 \%$ levels.

The notation used in the above Table is defined as follows: MAN is the percentage of capital held by the managers; CON is the percentage of capital held by the largest shareholder; INST is the percentage of capital held by the institutional investors; FSIZE is the natural logarithm of market value of equity; LEV is the ratio of total debt to total assets; GROW is the market-to-book ratio equal to the report between the market value and the book value of equity; IFRS is a dummy variable that takes the value of 1 for observations in the post-IFRS period and 0 otherwise.

which imply a net dispersion of this variable between firms in our sample. The average debt rate for the total sample is $23.1 \%$, which shows that the weighting of debts is relatively low in our sample firms. We also note that the ratio of market-to-book has an average greater than 1 on the order of 2.443 . This result reveals that the firms in our sample have strong growth opportunities since the market value of the shares exceeds their book value.

\subsection{Correlation analysis}

To verify the absence of multicollinearity problem between the independent variables, we calculated the Spearman correlation coefficients.

Table 2 presents the Spearman correlation matrix. The examination of this Table shows that all correlation coefficients are below 0.7, which corresponds to the limit set by Kervin (1992) from which we may generally have a serious problem of multicollinearity. Accordingly, we note that the independent variables in our regression models are weakly correlated and we conclude the absence of a multicollinearity problem.

\subsection{Multivariate analysis}

In the context of the multivariate analysis, we present and analyze the results of different regression models testing the relationship between the ownership structure and the quality of accounting earnings measured by the earnings management and informativeness.

\subsubsection{Analysis of the relationship between ownership structure and earnings management}

Table 3 reports the results of model 1 which examines the linear relationship between ownership structure and earnings manage- ment. Additionally, Table 3 presents the results of model 2 which examines the non-linear relationship between ownership structure and earnings management.

Analysis of the linear relationship between ownership structure and earnings management

The estimation results of model 1 show that managerial ownership contributes to an increase of discretionary accruals and a reduction of earnings quality since the coefficient associated with the variable MAN is positive (0.0219) and statistically significant at the $5 \%$ level. The significance of this coefficient leads us to accept the hypothesis $\mathrm{H} 1$ assuming the existence of a relationship between managerial ownership and earnings quality. This result, which is similar to those found by Cheng \& Warfield (2005), Al-Fayoumi et al. (2010) and Charfeddine et al. (2013), finds its justification in the entrenchment hypothesis. In fact, when the level of management ownership is high, the managers escape all control and entrench. They seek to increase their discretionary power and maximize their wealth at the expense of other firm partners, which imply a reduction of earnings quality. In this context, we argue that, in the French context, managers with higher equity ownership are more likely to act opportunistically and manage earnings. The multivariate analysis results reveal that the other aspects of ownership structure such as ownership concentration and institutional ownership do not play an effective role in monitoring management activities having regard to the non-significance of the coefficients. Thus, the hypotheses $\mathrm{H} 2$ and $\mathrm{H} 3$ are rejected.

Regarding the control variables, we find that the size and the growth of the firm are the only factors which have a probable impact on the earnings management. With respect to the firm size, the coefficient associated with the variable FSIZE is negative and statistically significant at the threshold of $1 \%$. This result is consistent with the idea that large companies are more subject to pressure from capital markets and, therefore, they seek to reduce the 
scope of managerial opportunism and to disclose a better quality of financial statements in order to attract potential investors. For the growth opportunities, we note that the coefficient associated with the variable GROW is positive (0.0048) and statistically significant at the level of $1 \%$. In this regard, high-growth firms are more likely to manage earnings to signal their future growth opportunities at the financial market.

Analysis of the non-linear relationship between ownership structure and earnings management

The estimation results of model 2 reveal the existence of a nonlinear relationship between ownership concentration and earnings management given that both linear and quadratic terms are statistically significant. For the linear term, the coefficient associated with the variable $\mathrm{CON}$ is negative (-0.0654). But for the quadratic term, the coefficient related to the variable $\mathrm{CON}^{2}$ is positive (0.0733). In this regard, we notice that the relationship between ownership concentration and discretionary accruals reverses from negative (linear term) to positive (quadratic term). This result corroborates the findings of Kammoun \& Bouazizi (2011) and supports both the convergence of interest and entrenchment hypotheses. Actually, the ownership concentration constitutes a mechanism of interests' alignment and a means allowing the reduction of earnings management practice. But when their participation exceeds a certain limit, the majority shareholders can act opportunistically at the expense of minority shareholders and can influence the firms to adopt accounting choices that reflect their interests rather than the economic reality.

The multivariate analysis results do not validate the non-linear relationship between managerial ownership and earnings management since the coefficients of the variables MAN and $\mathrm{MAN}^{2}$ are not statistically significant.

Also, the examination of this Table shows that the coefficients of the variables INST and INST ${ }^{2}$ are not statistically significant. So, the non-linear relationship between institutional ownership and earnings management is not confirmed.

Concerning the control variables, we do not find any significance regarding the variables related to the leverage and the adoption of IFRS. But, we find that the variables FSIZE and GROW retain their signs compared to the first model. The firm size is negatively and significantly associated to the earnings management. While the relationship between firm growth and absolute value of discretionary accruals remains positive and significant.

\subsubsection{Analysis of the relationship between ownership structure and earnings informativeness}

Table 4 displays the results of model 3 which examines the linear relationship between ownership structure and earnings informativeness. Equally, Table 4 provides the results of model 4 which examines the non-linear relationship between ownership structure and earnings informativeness.

Table 4: Regression Results Examining the Relationship between Ownership Structure and Earnings Informativeness

\begin{tabular}{|c|c|c|c|c|}
\hline \multirow{2}{*}{ Variables } & \multicolumn{2}{|l|}{ Model 3} & \multicolumn{2}{|l|}{ Model 4} \\
\hline & Coefficients & $\mathrm{Z}$ & Coefficients & $\mathrm{Z}$ \\
\hline Intercept & 0.2899 & 1.53 & 0.2702 & 1.46 \\
\hline EPS & 1.8079 & $2.63 * * *$ & 3.5823 & $4.17 * * *$ \\
\hline MAN*EPS & 2.5774 & 1.59 & -1.1366 & -0.16 \\
\hline $\mathrm{MAN}^{2} * \mathrm{EPS}$ & & & 12.3470 & 1.04 \\
\hline CON* EPS & 3.5510 & $8.73^{* * *}$ & -11.5139 & $-2.84 * * *$ \\
\hline $\mathrm{CON}^{2} * \mathrm{EPS}$ & & & 15.1288 & $3.67 * * *$ \\
\hline INST*EPS & 3.2532 & $3.54 * * *$ & 6.2798 & $2.17 * *$ \\
\hline $\mathrm{INST}^{2} * \mathrm{EPS}$ & & & -7.7947 & $-2.21 * *$ \\
\hline FSIZE*EPS & -0.3966 & $-4.19 * * *$ & -.1492 & -1.43 \\
\hline LEV*EPS & 0.7427 & 1.04 & -3.5628 & $-2.17 * *$ \\
\hline GROW*EPS & 0.0458 & 1.04 & 0.0566 & 1.15 \\
\hline IFRS*EPS & -0.5109 & -1.21 & 0.1128 & 0.20 \\
\hline $\mathrm{N}$ & 1049 & & 1049 & \\
\hline $\mathrm{R}^{2}$ & 0.4535 & & 0.4721 & \\
\hline Wald chi 2 & $1930.66 * * *$ & & $2625.52 * * *$ & \\
\hline
\end{tabular}

$* *, * * *$ represent statistical significance at $5 \%$ and $1 \%$ levels

The notation used in the above Table is defined as follows: EPS is the earnings-pershare in year $\mathrm{t}$ standardized by the stock price in year t-1; MAN is the percentage of capital held by the managers; $\mathrm{CON}$ is the percentage of capital held by the largest shareholder; INST is the percentage of capital held by the institutional investors;
FSIZE is the natural logarithm of market value of equity; LEV is the ratio of total debt to total assets; GROW is the market-to-book ratio equal to the report between the market value and the book value of equity; IFRS is a dummy variable that takes the value of 1 for observations in the post-IFRS period and 0 otherwise.

\section{Analysis of the linear relationship between ownership struc-} ture and earnings informativeness

The estimation results of model 3 show that the coefficient associated with the variable EPS is positive (1.8079) and statistically significant at the $1 \%$ level. Like Sánchez-Ballesta \& García-Meca (2007), we can conclude that the stock return can be explained by the accounting earnings in the French context.

The results depicted in Table 4 reveal that the coefficient associated with the variable MAN*EPS is insignificant, which leads us to refute the hypothesis H1. Thus, we argue that the managerial ownership does not seem to have an impact on the earnings informativeness in the French context.

With respect to the ownership concentration, we find a positive association between the ownership concentration and the information content of accounting earnings owing to the fact that the coefficient related to the variable CON*EPS is positive (3.5510) and significant at the threshold of $1 \%$. Given the significance of the coefficient, our hypothesis $\mathrm{H} 2$ is accepted. This result, which is similar to that found by Jung \& Kwon (2002), can be justified by referring to the convergence of interest hypothesis. In fact, the presence of a majority shareholder involved and active is beneficial for the company to the extent that it reduces managerial opportunism and, therefore, leads to more informative accounting earnings.

It appears from the Table that the institutional ownership is positively associated with the earnings informativeness. Actually, the coefficient related to the interaction term between the institutional ownership and the earnings-per-share normalized by the stock price at the beginning of the period is positive (3.2532) and significant at the $1 \%$ level. The significance of this coefficient leads us to validate the hypothesis H3. This result, which is consistent with those of Jung \& Kwon (2002), Kwak \& Armitage (2009) and Sarikhani \& Ebrahimi (2011), confirms the view that the institutional investors play an active role in monitoring and disciplining managers and, therefore, contribute to improve the quality of accounting earnings.

With regard to the control variables, the regression results indicate that only the firm size has a negative and significant effect on the informativeness of earnings. This result tends to confirm the political visibility hypothesis according to which large firms are more exposed to political pressures rather than small firms and are more prone to a large transfer of wealth. In this case, the larger firms are more likely to make accounting choices which reduce political costs and earnings informativeness. The other control variables such as leverage, growth and adoption of IFRS do not seem to have a significant effect on the information content of accounting earnings.

Analysis of the non-linear relationship between ownership structure and earnings informativeness

The estimation results of model 4 show that the ratio of earningsper-share in year $\mathrm{t}$ standardized by stock price in year $\mathrm{t}-1$ continues to be an explanatory factor of stock return. Thus, the accounting earning constitutes relevant information for investors on the French financial market.

Regarding the ownership structure, we do not find any relationship between the managerial ownership and the earnings informativeness given that both linear and quadratic terms are not significant. But as regards of ownership concentration, we find that both linear and quadratic terms are significant at the threshold of $1 \%$. The coefficient is negative for the linear term and positive for the quadratic term. Unlike Sánchez-Ballesta \& García-Meca (2007), we confirm the existence of a non-linear relationship between the existence of majority shareholder and the information usefulness of accounting earnings. At a low level of ownership concentration, the earnings informativeness is low according to the proprietary information and the human specific capital hypotheses. In this case, concentrated control limits information flow to 
the public and leads to opaque financial reporting. But, at a high level of ownership concentration, the earnings informativeness gets better pursuant to the convergence of interest and the efficient monitoring hypotheses.

We also note the existence of a non-linear relationship between the institutional ownership and the information content of accounting earnings since both linear and quadratic terms are significant at the level of $5 \%$. The coefficient is positive for the linear term and negative for the quadratic term. Contrary to all expectations, the reached results highlight a positive relationship between institutional ownership and earnings informativeness, but with institutional ownership concentration, this relationship reverses and becomes negative.

With respect to the control variables, the empirical results show that the level of debt is negatively related to the earnings informativeness since the coefficient associated with the variable LEV*EPS is negative (-3.5628) and significant at 5\% level. This result supports the findings of Vafeas (2000) and Petra (2007). Actually, the leaders of highly leveraged companies are more incited to manage earnings upwards with the aim to reassure creditors that the company is able to honor its future commitments and in this case the accounting earnings become less informative. Finally, it appears that the other control variables such as size, growth and adoption of IFRS do not have any significant influence on the earnings informativeness.

\section{Conclusion}

The objective pursued throughout this study is to identify the nature of the relationship between the ownership structure and the quality of accounting earnings as measured by the earnings management and informativeness. To meet our target, we tested both eventualities of linear and non-linear relationship for each attribute of the earnings quality and, therefore, we proposed four regression models.

The results of linear regressions show that, on the one hand, the managerial ownership has a positive impact on the earnings management and, on the other hand, the ownership concentration and the institutional ownership have a positive impact on the earnings informativeness.

The results of non-linear regressions reveal a negative relationship between the ownership concentration and the earnings management and a negative relationship between the ownership concentration and the earnings informativeness, which are reversed when the percentage of capital held by majority shareholder exceeds a certain threshold. Also, the results of non-linear regressions show the existence of a positive relationship between the institutional ownership and the earnings informativeness which is reversed when the percentage of capital held by the institutional investors exceeds a certain limit.

Overall, these results allow us to rule on the crucial role played by the ownership structure in terms of earnings quality in the French context. In this regard, we hope that our study contributes to the extant literature because it provides insight into the impact of ownership structure on earnings management and informativeness. The findings of this study may be subject to several limitations that could be platforms for future research. The first limit concerns the measure of institutional ownership considering institutional investors as a homogenous group pursuing the same objectives and the same behaviors. So, according to Brickley et al. (1988), the behavior of institutional investors depends on the category to which they belong. These authors argue that pension funds and investment companies are regarded as active or dedicated institutional investors, however banks and insurance companies are considered as passive or transient institutional investors. In this regard, in future researches we propose to expand and refine our study taking into account the heterogeneity of institutional investors. The second limit concerns the use of only two indicators of accounting quality based on earnings management and informativeness. Thus, it would be interesting to extend this study by incorporating other aspects of the earnings quality such as accruals quality, persistence, predictability, conservatism and timeliness. The third limit corresponds to the neglect of other corporate governance mechanisms, such as board of directors, audit committee and auditor quality, which may have a probable impact on the earnings quality. So, we propose to introduce these mechanisms in order to enrich this research.

\section{References}

[1] Al-Fayoumi N, Abuzayed B \& Alexander D (2010) Ownership structure and earnings management in emerging markets: The case of Jordan. International Research Journal of Finance and Economics 38, 28 47.

[2] Ali SM, Salleh NM \& Hassan MS (2008) Ownership structure and earnings management in Malaysian listed companies: the size effect. Asian Journal of Business and Accounting 1(2), 89-116.

[3] Alves S (2012) Ownership structure and earnings management: Evidence from Portugal. Australasian Accounting Business \& Finance Journal 6(1), 57-73.

[4] Banderlipe MR (2009) the impact of selected corporate governance variables in mitigating earnings management in the Philippines. DLSU Business \& Economics Review 19(1), 17-27.

[5] Beck N \& Katz JN (1995) what to do (and not to do) with time-series cross-section data. American Political Science Review 89(3), 634-647.

[6] Ben Slama F, Matoussi H \& Pigé B (2007) Gouvernance d'entreprise et pouvoir informationnel des bénéfices comptables en France et aux Etats-Unis. $28^{\text {ème }}$ Congrès de l'Association Francophone de Comptabilité, Poitiers, 1-16.

[7] Brickley JA, Lease RC \& Smith CW (1988) Ownership structure and voting on anti-takeover amendments. Journal of Financial Economics 20, 267-291.

[8] Bushee BJ (1998) the influence of institutional investors on myopic R\&D investment behavior. The Accounting Review 73(3), 305-333.

[9] Charfeddine L, Riahi R \& Omri A (2013) the determinants of earnings management in developing countries: A study in the Tunisian context. The IUP Journal of Corporate Governance XII (1), 35-49.

[10]Chekili S (2012) Impact of some governance mechanisms on earnings management: An empirical validation within the Tunisian market. Journal of Business Studies Quarterly 3(3), 95-104.

[11]Cheng CSA \& Reitenga A (2001) Characteristics of institutional investors and discretionary accruals. SSRN Working Paper, 1-37.

[12]Cheng Q \& Warfield TD (2005) Equity incentives and earnings management. The Accounting Review 80(2), 441-476.

[13]Chung R, Firth M \& Kim JB (2002) Institutional monitoring and opportunistic earnings management. Journal of Corporate Finance 8 , 29-48.

[14]Donnelly R \& Lynch C (2002) the ownership structure of UK firms and the informativeness of accounting earnings. Accounting and Business Research 32, 245-257

[15]Ebrahim A (2007) Earnings management and board activity: An additional evidence. Review of Accounting and Finance 6(1), 42-58.

[16]Ellili NOD (2013) the ownership structure, the board of directors and the quality of accounting information. Corporate Ownership \& Control 10(4), 420-433.

[17]Emamgholipour M, Bagheri SMB, Mansourinia E \& Arabi AM (2013) A study on relationship between institutional investors and earnings management: Evidence from the Tehran Stock Exchange. Management Science Letters 3, 1105-1112.

[18]Fan JPH \& Wong TJ (2002) corporate ownership structure and the informativeness of accounting earnings in East Asia. Journal of Accounting and Economics 33, 401- 425.

[19]Firth M, Fung PMY \& Rui OM (2006) Ownership, board structure, and the informativeness of earnings-Evidence from an emerging market. SSRN Working Paper, 1-37.

[20]Francis J, Olsson P \& Shipper K (2006) Earnings quality. Foundations and Trends in Accounting 1(4), 259-340.

[21] Gabrielsen G, Gramlich JD \& Plenborg P (2002) Managerial ownership, information content of earnings and discretionary accruals in a non US setting. Journal of Business, Finance and Accounting 29(7-8), 967-988.

[22] Ghosh a \& Moon D (2010) the effect of CEO ownership on the information content of reported earnings. Review of Quantitative Finance \& Accounting 35, 393-410.

[23]González JS \& García-Meca E (2013) Does corporate governance influence earnings management in latin american markets?. Journal of Business Ethics, 1-22. 
[24]Hadani M, Goranova M \& Khan R (2011) Institutional investors, shareholder activism, and earnings management. Journal of Business Research 64, 1352-1360.

[25]Halioui K \& Jerbi A (2012) the effect of blockholders on earnings management: The case of Tunisian listed firms. International Journal of Multidisciplinary Research 2(2), 37-49.

[26]Hashim HA \& Devi SS (2012) Institutional monitoring and earnings quality in Malaysia. Procedia Social and Behavioral Sciences 65, 419426.

[27]Jiambalvo J, Rajgopal S \& Venkatachalam M (2002) Institutional ownership and the extent to which stock prices reflect future earnings. Contemporary Accounting Research 19(1), 117-145.

[28]Jung K \& Kwon SY (2002) Ownership structure and earnings informativeness: Evidence from Korea. The International Journal of Accounting 25, 301-325.

[29]Kammoun A \& Bouazizi S (2011) Structure de propriété, accruals discrétionnaires et pouvoir informationnel du bénéfice : Etude sur des entreprises tunisiennes. Recherche en Comptabilité et Finance 6, 5778.

[30]Kervin JB (1992) Methods for business research. New York: Harpet Collins.

[31]Koh P-S (2003) on the association between institutional ownership and aggressive corporate earnings management in Australia. The British Accounting Review 35(2), 105-128.

[32]Kothari SP, Leone AJ \& Wasley CE (2005) Performance matched discretionary accruals. Journal of Accounting and Economics 39(1), 23-49.

[33]Kwak W \& Armitage J (2009) Earnings informativeness and ownership structure in Japan. The Journal of Applied Business Research 25(1), 13-20

[34]Morck R, Shleifer a \& Vishny RW (1988) Management ownership and market valuation. Journal of Financial Economics 20, 293-315.

[35]Njah M \& Jarboui A (2010) Les pratiques de gestion des résultats sont-elles influencées par l'institutionnalisation de l'actionnariat? Recherches en Comptabilité ET Finance 5, 3-25.

[36]Petra ST (2007) the effects of corporate governance on the informativeness of earnings. Economics of Governance 8(2), 129-152.

[37]Salajeghe S, Montazer MN, Nourollahi N, Valipour J \& HorMohammadi M (2012) Earnings management and companies' ownership structure in Iran (A Comparison of Earnings Management between companies with institutional investors and companies with individual investors). Journal of Basic and Applied Scientific Research 2(2) $1728-1734$.

[38]Sánchez-Ballesta JP \& García-Meca E (2007) Ownership structure discretionary accruals and the informativeness of earnings. Corporate Governance: An International Review 15, 677-691.

[39]Sarikhani M \& Ebrahimi M (2011) corporate governance and earnings informativeness: Evidence from Iran. International Research Journal of Finance and Economics 65, 43-50.

[40]Schipper K (1989) Commentary on earnings management. Accounting Horizons 3(4), 91-102.

[41]Teshima N \& Shuto A (2008) Managerial ownership and earning management: Theory and empirical evidence from Japan. Journal of International Financial Management and Accounting 19, 107-132.

[42]Usman SH \& Yero JI (2012) Ownership concentration and earnings management practice of nigerian listed conglomerates. American International Journal of Contemporary Research 2(7), 157-171.

[43] Vafeas N (2000) Board structure and the informativeness of earnings. Journal of Accounting and Public Policy 19(2), 139-160.

[44] Velury U \& Jenkins DS (2006) Institutional ownership and the quality of earning. Journal of Business Research 59, 1043-1051.

[45]Warfield TD, Wild JJ \& Wild KL (1995) Managerial ownership, accounting choices and the informativeness of earnings. Journal of Accounting and Economics 20, 61-91.

[46] Yeo GHH, Tan PMS, Ho KW \& Chen SS (2002) corporate ownership structure and the informativeness of earnings. Journal of Business Finance and Accounting 29(7-8), 1023-1046. 